\title{
SMAD2 disruption in mouse pancreatic beta cells leads to islet hyperplasia and impaired insulin secretion due to the attenuation of ATP-sensitive $\mathrm{K}^{+}$channel activity
}

\author{
Masatoshi Nomura $\cdot$ Hai-Lei Zhu $\cdot$ Lixiang Wang • \\ Hidetaka Morinaga $\cdot$ Ryoichi Takayanagi $\cdot$ Noriyoshi Teramoto
}

Received: 7 June 2013 / Accepted: 26 August 2013 / Published online: 26 September 2013

(C) Springer-Verlag Berlin Heidelberg 2013

\begin{abstract}
Aims/hypothesis The TGF- $\beta$ superfamily of ligands provides important signals for the development of pancreas islets. However, it is not yet known whether the TGF- $\beta$ family signalling pathway is required for essential islet functions in the adult pancreas.

Methods To identify distinct roles for the downstream components of the canonical TGF- $\beta$ signalling pathway, a Cre-loxP system was used to disrupt SMAD2, an intracellular transducer of TGF- $\beta$ signals, in pancreatic beta cells (i.e. Smad $2 \beta$ knockout $[\mathrm{KO}]$ mice). The activity of ATP-sensitive $\mathrm{K}^{+}$channels ( $\mathrm{K}_{\mathrm{ATP}}$ channels) was recorded in mutant beta cells using patchclamp techniques.

Results The Smad $2 \beta \mathrm{KO}$ mice exhibited defective insulin secretion in response to glucose and overt diabetes. Interestingly, disruption of SMAD2 in beta cells was associated with a striking islet hyperplasia and increased pancreatic insulin content, together with defective glucose-responsive insulin secretion. The activity of $\mathrm{K}_{\text {ATP }}$ channels was decreased in mutant beta cells.

Conclusions/interpretation These results suggest that in the adult pancreas, TGF- $\beta$ signalling through SMAD2 is crucial for not only the determination of beta cell mass but also the maintenance of defining features of mature pancreatic beta

Electronic supplementary material The online version of this article (doi:10.1007/s00125-013-3062-2) contains peer-reviewed but unedited supplementary material, which is available to authorised users.
\end{abstract}

M. Nomura $\cdot$ L. Wang $\cdot H$. Morinaga $\cdot$ R. Takayanagi

Department of Medicine and Bioregulatory Science, Graduate

School of Medical Sciences, Kyushu University, Higashi Ward,

Fukuoka, Japan

H.-L. Zhu $\cdot$ H. Morinaga $\cdot$ N. Teramoto $(\triangle)$

Department of Pharmacology, Faculty of Medicine, Saga University,

5-1-1, Nabeshima, Saga 849-8501, Japan

e-mail: noritera@cc.saga-u.ac.jp cells, and that this involves modulation of $\mathrm{K}_{\mathrm{ATP}}$ channel activity.

Keywords Insulin $\cdot \mathrm{K}_{\mathrm{ATP}}$ channels $\cdot$ Pancreatic beta cells $\cdot$ SMAD2 - TGF- $\beta$

$\begin{array}{ll}\text { Abbreviations } & \\ \text { ActRIIA } & \text { Activin receptor type II A } \\ \text { ActRIIB } & \text { Activin receptor type II B } \\ \text { ALK7 } & \text { Activin receptor-like kinase } 7 \\ \text { BrdU } & \text { Bromodeoxyuridine } \\ \text { FSTL3 } & \text { Follistatin-like 3 } \\ \text { GAPDH } & \text { Glyceraldehyde-3-phosphate } \\ & \text { dehydrogenase } \\ \text { GDF11 } & \text { Growth differentiation factor 11 } \\ \text { K } & \text { ATP channels } \\ \text { Kir6.x } & \text { Inwardly rectifying K }{ }^{+} \text {channel } 6 \text { family } \\ \text { KO } & \text { Knockout } \\ \text { NTS } & \text { Nucleus tractus solitarius } \\ \text { Rip } & \text { TgN(ins2-Cre)25Mgn } \\ \text { Smad2 } \beta \text { KO } & \text { Smad2 conditional knockout in pancreatic } \\ \text { SUR } & \text { beta cells } \\ \text { TUNEL } & \text { Sulfonylurea receptor } \\ & \text { Terminal deoxynucleotidyl transferase- } \\ & \text { mediated UTP end labelling }\end{array}$

\section{Introduction}

The ongoing obesity pandemic in many developed countries has increased the prevalence of insulin resistance and diabetes. A decline in pancreatic beta cell numbers or function, with impaired regulation of glucose metabolism, is often exacerbated by peripheral insulin resistance, requiring increased 
insulin output from the remaining healthy beta cells. Thus, there is considerable interest in targeting signalling pathways to enhance beta cell function and mass. Recent studies have revealed that members of the TGF- $\beta$ family mediate pancreatic beta cell development and function $[1,2]$.

The TGF- $\beta$ superfamily (including TGF- $\beta$ isoforms and activins) has a significant role in many cellular functions and embryonic development $[3,4]$. The signal is transduced intracellularly by SMAD proteins [5]: after phosphorylation, receptor-regulated SMADs (SMAD1, 2, 3, 5 and 8) bind to SMAD4, and the complexes regulate transcription of target genes. Signal transduction through these pathways is blocked by SMAD6 and SMAD7 (inhibitory SMADs), which suppress phosphorylation. SMAD2 and SMAD3 act in both the TGF- $\beta$ and activin signalling pathways.

TGF- $\beta$ /activin signalling is a major regulator of pancreatic endocrine and exocrine cell fate during embryonic development $[1,2]$. Components of TGF- $\beta$ /activin signalling have been detected in mature rat, mouse and human islets [6-9], suggesting additional roles in adult islet function. Indeed, TGF- $\beta$ and activin can stimulate insulin secretion from rat and human islets in vitro [10-12]. However, multiple developmental defects severely limit the use of null mutants of type I and II activin receptors as models for studying TGF- $\beta$ and activin in adult pancreatic islets. Mice with reduced expression of activin receptor type IIA (ActRIIA) or IIB (ActRIIB) have hypoplastic islets and glucose intolerance [13], while mice heterozygous for the SMAD2 null allele exhibit embryonic and adult endocrine pancreatic defects $[14,15]$. Compound heterozygous ActRIIB/SMAD2 mice show an exacerbated phenotype, with reduced islet area, insulin content and glucose tolerance, implicating SMAD2 as a downstream mediator of ActRIIB that plays an important role in adult islet functions [15]. Furthermore, SMAD2 signalling is involved in the differentiation of pancreatic AR42J cells into insulinsecreting cells [16] and SMAD7 overexpression in adult pancreatic beta cells leads to islet hypoplasia and impaired glucose tolerance [17]. These observations indicate that TGF- $\beta /$ activin signalling through SMAD2/SMAD3 plays a positive role in both beta cell function (insulin secretion) and maintenance of beta cell mass. In contrast, SMAD3-deficient mice exhibit enhanced glucose tolerance and insulin secretion with minimal change in beta cell mass. Isolated SMAD3-deficient islets secrete more insulin in response to glucose than wildtype islets [18], implying that SMAD3 activation inhibits insulin production and secretion whereas inactivation increases glucose-induced insulin secretion. Despite the evidence that TGF- $\beta$ /activin signalling regulates pancreas islet function, the role of SMAD2 in beta cells remains elusive.

Here, the role of SMAD2 in pancreatic beta cells has been investigated by comparing control mice with $\operatorname{Smad} 2 \beta$ knockout (KO) mice exhibiting conditional knockdown of SMAD2 in beta cells $(\operatorname{Smad} 2 \beta \mathrm{KO})$. We demonstrate that SMAD2 is important for regulating pancreas islet function and maintaining beta cell mass. Strikingly, pancreatic beta cell-specific SMAD2 disruption leads to islet hyperplasia and impaired glucose tolerance, with decreased activity of ATP-sensitive $\mathrm{K}^{+}\left(\mathrm{K}_{\text {ATP }}\right)$ channels. This suggests that TGF- $\beta$ signalling through SMAD2 is crucial for maintaining the defining features of mature pancreatic beta cells in the adult pancreas and $\mathrm{K}_{\text {ATP }}$ channel activity, and determining beta cell mass during embryogenesis, providing potential novel site(s) to target the treatment of diabetes.

\section{Methods}

Generation of mice with pancreatic beta cell-specific Smad2 deletion Mouse experiments were performed according to the guidelines of the animal ethics committee of Kyushu University Graduate School of Medicine. Smad $2^{\text {flox } /++}$ mice, generated as previously described [19], were backcrossed with C57BL $/ 6$ mice for eight generations. Female Smad $2^{\text {flox } /+}$ mice were crossed with male transgenic mice expressing Cre recombinase under the control of rat insulin gene regulatory elements (TgN(ins2-Cre)25Mgn, hereafter 'Rip'); the resulting Rip-Smad2 ${ }^{\text {flox/++ }}$ mice were crossed with $S \operatorname{mad} 2^{\text {flox/+ }}$ mice. Mice lacking SMAD2 in pancreatic beta cells (Rip$\operatorname{Smad} 2^{\text {flox/flox }}$ Smad2 $\beta \mathrm{KO}$ ) were generated at the expected Mendelian ratio. The primers used for genotyping (PCR) for the Smad 2 conditional allele and Rip transgene are shown in electronic supplementary material (ESM) Table 1.

Analysis of pancreatic islets Pancreatic islets of non-fasted Smad $2 \beta \mathrm{KO}$ and control Rip mice (4-6 months old) were isolated as previously described [20]. In brief, mice were killed and Hanks' solution (Life Technologies, Carlsbad, CA, USA) containing collagenase IV (Worthington Biochemical, Lakewood, NJ, USA) was injected into the biliary tract. The pancreas was excised and incubated $\left(13 \mathrm{~min}, 37^{\circ} \mathrm{C}\right)$, and the resulting suspension washed (Hanks' solution, $3 \times$ ) and centrifuged (1 min, 1,000 rpm). Islets were obtained using a density gradient (HISTOPAQE-1077 and -1119; Sigma-Aldrich, Tokyo, Japan) and then selected visually with a stereomicroscope. For measurement of insulin secretion, pancreatic islets from mice (4-6 months old) were pooled, cultured for $16 \mathrm{~h}$ in RPMI 1640 medium (Sigma-Aldrich) containing 10\% FBS $\left(37^{\circ} \mathrm{C}, 5 \% \mathrm{CO}_{2}\right.$ in air) and transferred to Krebs-Ringer HEPES buffer (mmol/l: $\mathrm{NaCl} 140, \mathrm{KCl} 3.6, \mathrm{NaH}_{2} \mathrm{PO}_{4} 0.5$, $\mathrm{MgSO}_{4}$ 0.5, $\mathrm{CaCl}_{2}$ 1.5, $\mathrm{NaHCO}_{3} 2$, HEPES 10 and $0.1 \%$ BSA) containing $(\mathrm{mmol} / \mathrm{l})$ glucose 2.8 , glucose 11.2 , tolbutamide 0.5 or $\mathrm{KCl} 60$; insulin secretion was assayed using a rat/mouse insulin ELISA kit (Morinaga Institute of Biological Science, Tokyo, Japan). For western blot analysis, islets were homogenised in lysis buffer (Tris $25 \mathrm{mmol} / \mathrm{l}, \mathrm{NaCl}$ $150 \mathrm{mmol} / \mathrm{l}$, EDTA $5 \mathrm{mmol} / \mathrm{l}, 1 \%$ Triton X-100, $0.5 \%$ deoxycholate and protease inhibitors) and the protein content 
was measured (BCA protein assay kit; Thermo Scientific, Rockford, IL, USA). Samples $(20 \mu \mathrm{g})$ were dissolved in Laemmli sample buffer (Bio-Rad, Hercules, CA, USA) with $5 \% 2$-mercaptoethanol and then heat-denatured $\left(100^{\circ} \mathrm{C}\right.$, $2 \mathrm{~min}$ ), electrophoresed (10\% polyacrylamide gel; Bio-Rad), electroblotted onto a polyvinylidine fluoride membrane (Millipore, Billerica, MA, USA), blocked with 4\% Block Ace in Tris-buffered saline and Tween 20 (room temperature, $5 \mathrm{~h}$ ) and incubated with rabbit anti-SMAD2 primary antibody (1:250; Cell Signaling Technology, Danvers, MA, USA) overnight at $4^{\circ} \mathrm{C}$. Secondary antibodies were peroxidase conjugated (1:1000; Cell Signaling Technology); the internal control was rabbit anti-mouse glyceraldehyde-3-phosphate dehydrogenase (GAPDH) antibody (1:1000; Santa Cruz Biotechnology, Santa Cruz, CA, USA). Protein bands were visualised with an ECL Plus Western Blotting Detection System (GE Healthcare, Little Chalfont, UK).

RNA isolation and semi-quantitative RT-PCR Total RNA was isolated from mouse islets (TRIzol Reagent; Invitrogen, Carlsbad, CA, USA) and purified (SV Total RNA Isolation System; Promega, Madison, WI, USA). RNA samples were quantified (ND-1000 spectrophotometer; NanoDrop Technologies, Wilmington, DE, USA) and their quality confirmed (Experion System; Bio-Rad). Total RNAs were reverse transcribed (QuantiTect Reverse Transcription Kit; Qiagen, Hilden, Germany); the resulting cDNAs were amplified in $25 \mu \mathrm{l}$ of GoTaq Green Master Mix (Promega). The primers used (Smad2 and Gapdh) are shown in ESM Table 2. Relative gene expression vs control was normalised to the expression of GAPDH genes. PCR products were separated on a $1.5 \%$ agarose gel and visualised by staining with ethidium bromide. The relative content of each sample was compared with internal controls using ImageJ 1.43u software (http://just-download. com/graphic-apps/editors/imagej-1.43u.rar/download/17fe1). RT-PCR experiments were repeated three times.

Quantitative real-time PCR analysis Total RNA (500 ng) was converted into first-strand cDNA (QuantiTect Reverse Transcription Kit; Qiagen), and quantitative real-time PCR undertaken using $2 \times$ Power SYBR Green PCR Master Mix and an ABI Prism 7,000 sequence detection system (Applied Biosystems). The PCR conditions were: $95^{\circ} \mathrm{C}$ for $10 \mathrm{~min}$, then 40 cycles at $95^{\circ} \mathrm{C}$ for $15 \mathrm{~s}$ and $60^{\circ} \mathrm{C}$ for $45 \mathrm{~s}$. The primer sequences used (Kir6.2, Sur1 and Gapdh) are shown in ESM Table 2. Relative gene expression vs control was normalised to the expression of GAPDH genes.

Metabolic measurements, insulin and glucose tolerance tests Mice had free access to normal food (CLEA rodent diet CE-2; $54.4 \%$ carbohydrate, $24.4 \%$ protein, $4.4 \%$ fat, 1.4 $\mathrm{MJ} / 100 \mathrm{~g}$; Kyudo, Saga, Japan) and were weighed weekly. The food intake of individually housed mice was measured every 4 min for 3 days using a food consumption monitor system (NeuroScience Idea, Osaka, Japan). Spontaneous physical activity was quantified (Letica infrared system; Panlab, Barcelona, Spain) as previously described [21]. Mice were fasted overnight and baseline glucose levels were measured using tail-vein blood (Glutest Sensor; Sanwa Kagaku, Nagoya, Japan). Glucose (1 mg/g body weight) in sterile PBS was injected intraperitoneally and blood glucose was assayed after 30, 60, 90 and $120 \mathrm{~min}$. To measure plasma insulin levels, $\sim 50 \mu \mathrm{l}$ of tail-vein blood was collected before, and 15 and $30 \mathrm{~min}$ after, intraperitoneal glucose injection. Wholepancreas insulin content was determined after acid-ethanol extraction.

Histology The whole pancreas was excised, weighed and cut into head (duodenal) and tail (spleen) parts. The tissues were fixed separately ( $4 \%$ paraformaldehyde, overnight, $4^{\circ} \mathrm{C}$ ), dehydrated (100\% ethanol), embedded in paraffin and sectioned $(5 \mu \mathrm{m})$. Every 30th section (11 sections per mouse) was stained with Mayer's hematoxylin (5 min), washed (distilled water), counterstained with $0.5 \%$ eosin alcohol (2 $\mathrm{min})$, dehydrated and mounted. For immunostaining of insulin, glucagon, Kir6.2 and sulfonylurea receptor 1 (SUR1), sections were subjected to antigen retrieval using Dako Cytomation Target Retrieval Solution (Dako, Carpinteria, CA, USA). After blockade with Block Ace (Dainippon Sumitomo, Osaka, Japan), sections were incubated with primary $\left(4^{\circ} \mathrm{C}, 12-16 \mathrm{~h}\right)$ and secondary $(1 \mathrm{~h})$ antibodies. The primary antibodies were guinea pig anti-porcine insulin (1:500), rabbit anti-human glucagon (1:500; Dako), goat anti-human Kir6.2 (1:200) and goat anti-human SUR1 (1:200; Santa Cruz Biotechnology). Alexa Fluor 594conjugated goat anti-guinea pig IgG and Alexa Fluor 488conjugated donkey anti-rabbit IgG (Molecular Probes, Eugene, OR, USA) were used as secondary antibodies for insulin and glucagon, respectively. Immunofluorescence was assessed using laser microscopy (BioZero; Keyence, Osaka, Japan). A horseradish peroxidase-linked secondary antibody was used for light microscopic observations of Kir6.2 and SUR1. For SMAD2 immunostaining, each pancreas was fixed (4\% paraformaldehyde in PBS, $1 \mathrm{~h}$, room temperature), cryoprotected in $10 \%$ sucrose $(2 \mathrm{~h})$, exposed to $30 \%$ sucrose overnight, embedded in optimal cutting temperature compound (Sakura, Kobe, Japan) and snap frozen (isopentane bath on dry ice). Transverse $16 \mathrm{~mm}$ cryosections were mounted onto Superfrost slide glasses (Matsunami, Osaka, Japan) and stored at $-80^{\circ} \mathrm{C}$ until use. The primary antibodies were: rabbit anti-SMAD2 and rabbit anti-phospho-SMAD2 (both 1:100; Cell Signaling Technology). Sections were incubated with horseradish peroxidase-linked secondary antibody for light microscopy. DNA fragmentation, a hallmark of apoptosis, was detected by in situ labelling with a terminal deoxynucleotidyl transferase-mediated UTP end labelling 
(TUNEL) assay (Chemicon, Temecula, CA, USA) and counterstained with $0.5 \%$ (wt/vol.) methyl green (Wako, Osaka, Japan). For bromodeoxyuridine (BrdU) labelling of islets, $5 \mathrm{mg} / \mathrm{ml} \mathrm{BrdU}$ solution was injected into the abdominal cavity $(0.1 \mathrm{mg} / \mathrm{g}$ body weight). The mice were killed after $4 \mathrm{~h}$ and the pancreases were processed as above. BrdU-positive cells were detected with anti-BrdU antibodies (BD Biosciences, San Jose, CA, USA) in sections treated with $0.2 \mathrm{mg} / \mathrm{ml}$ pepsin in $2 \mathrm{~mol} / \mathrm{l} \mathrm{HCl}\left(20 \mathrm{~min}, 37^{\circ} \mathrm{C}\right)$. Sections were examined using a BZ-8000 microscope (Keyence).

Morphometric analyses Computer-assisted measurements of pancreatic islet area (BioZero microscope; Keyence) were analysed using Microsoft Excel software (Mac 2011 version 14.3.5: Microsoft Japan, Tokyo, Japan). The islets were classified according to their area: $<2,500 \mu \mathrm{m}^{2}$ was defined as small, $2,500-10,000 \mu \mathrm{m}^{2}$ as medium and $>10,000 \mu \mathrm{m}^{2}$ as large.

Electrophysiological experiments The patch-clamp and data recording systems were as described previously [22]; experiments were performed at room temperature $\left(21-23^{\circ} \mathrm{C}\right)$. Whole-cell currents were low-pass filtered at $500 \mathrm{~Hz}$ (continuous traces) or $2 \mathrm{kHz}$ (ramp currents), sampled at $10 \mathrm{~ms}$ (continuous traces) or $1 \mathrm{~ms}$ (ramp currents) intervals and analysed using a MacBook Pro (Apple Japan, Tokyo, Japan) running Chart v5.5.6 software (ADInstruments, Castle Hill, Australia). Macroscopic current peak amplitudes (pA) were normalised by cell-capacitance $(\mathrm{pF})$, with current density expressed as $\mathrm{pA} / \mathrm{pF}$. The bath solution contained (mmol/l) $\mathrm{NaCl} 5, \mathrm{KCl} 140, \mathrm{MgCl}_{2} 1.2, \mathrm{CaCl}_{2}$ 2, glucose 5 and HEPES 10 , $\mathrm{pH} 7.35-7.40$ and the pipette solution contained (mmol/1) $\mathrm{KCl} 140$, glucose 5, EGTA 5, ATP-Tris 0.5 and HEPES 10, $\mathrm{pH}$ 7.35-7.40. The concentration-response curves for sulfonylurea drugs (glibenclamide and tolbutamide) were drawn using a least-squares fitting method according to the equation: relative current value $=1 /\left[1+\left(K_{i} / \mathrm{D}\right)^{\mathrm{n}_{\mathrm{H}}}\right]$, where $K_{i}$, D and $\mathrm{n}_{\mathrm{H}}$ are the inhibitory dissociation constant, the concentration of the sulfonylurea drug $(\mu \mathrm{mol} / \mathrm{l})$ and the Hill coefficient, respectively.

Statistical analysis Data are expressed as mean \pm SEM. Differences between sample means were assessed by ANOVA followed by the Newman-Keuls multiple comparison test. $p<0.05$ was considered to be statistically significant.

\section{Results}

Disruption of SMAD2 in beta cells To confirm cell lineagespecific Smad2 gene deletion in Smad2 $\beta$ KO mice, genomic DNA was prepared from various tissues and the $\mathrm{KO}$ allele was analysed by Southern blotting [19]. In Smad $2 \beta$ KO mice,
Smad2 alleles were almost completely deleted in the islets, partially deleted in the hypothalamus and not deleted in the other tissues examined (Fig. 1a). Islet SMAD2 expression was further investigated at both the transcript (Fig. 1b) and protein (Fig. 1c) level.

SMAD2 was almost completely ablated in mutant mouse islets ( $90 \%$ loss). Mouse SMAD2 antiserum produced cytoplasmic staining of islet cells in control Rip but not Smad $2 \beta$ KO mice (Fig. 1d). Phospho-SMAD2 antibody produced weak but distinct nuclear staining in control mice and no staining in Smad2 $\beta \mathrm{KO}$ mice (Fig. 1d), confirming substantial block of SMAD2 signalling in Smad2 $\beta$ KO mouse beta cells.

Diet-induced obesity in Smad2 $\beta$ KO mice From 16 weeks onwards, body weight was significantly greater in Smad $2 \beta$ KO mice than in controls (Fig. 2a). Food intake was increased in Smad $2 \beta \mathrm{KO}$ mice during the light and dark cycles (Fig. 2b-d), possibly underlying the body weight differences. Interestingly, Smad $2 \beta \mathrm{KO}$ mice moved less than control mice during the active dark cycle, but not during the light cycle when mice were less active (Fig. 2e, f). Less physical activity may also have contributed to the increased body weight of Smad $2 \beta \mathrm{KO}$ mice, although it is unlikely that this extra weight physically limited their movement. At 14 weeks, fasting serum leptin levels were significantly higher in $\operatorname{Smad} 2 \beta \mathrm{KO}$ mice than in controls (Fig. 2g, h), suggesting that the former were leptin-resistant. Interestingly, a high leptin level in Smad $2 \beta$ KO mice was observed at 14 weeks at which time body weight was indistinguishable from that of controls.
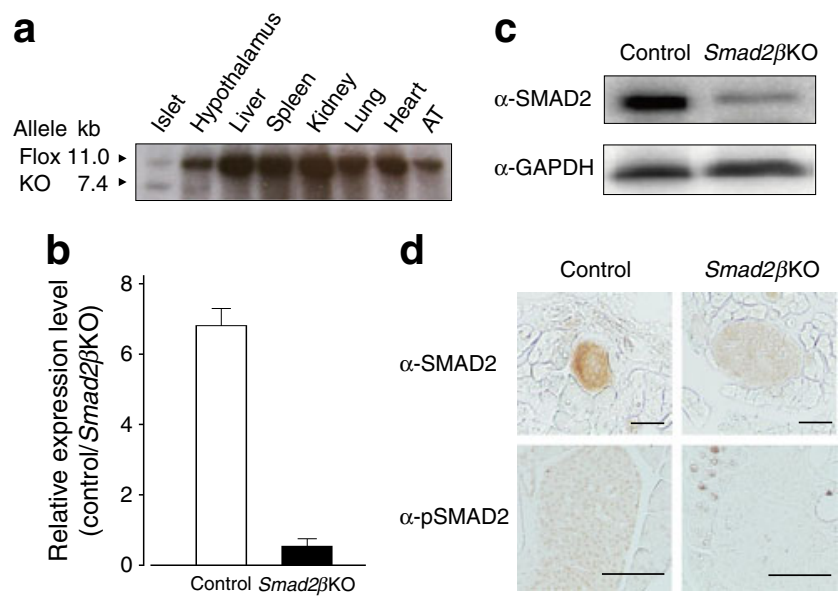

Fig. 1 Conditional Smad2 targeting allows beta cell-specific Smad2 knockout. (a) Southern blot analysis of DNA from tissues of $S m a d 2 \beta \mathrm{KO}$ mice to detect Cre-mediated recombination. The $7.4 \mathrm{~kb}$ band representing the $\mathrm{KO}$ allele is evident in the lanes corresponding to the pancreatic islets and hypothalamus. AT, adipose tissue. (b) Quantitative RT-PCR analysis of RNA obtained from pancreatic islets of control Rip and Smad $2 \beta \mathrm{KO}$ mice. (c) Western blotting analysis of Smad2 protein in pancreas islets from control Rip and Smad $2 \beta \mathrm{KO}$ mice; GAPDH was used as an internal control. (d) Immunohistochemical analysis of the expression of Smad2 protein and phospho-Smad2 protein in pancreatic islets. Scale bar, $50 \mu \mathrm{m}$ 


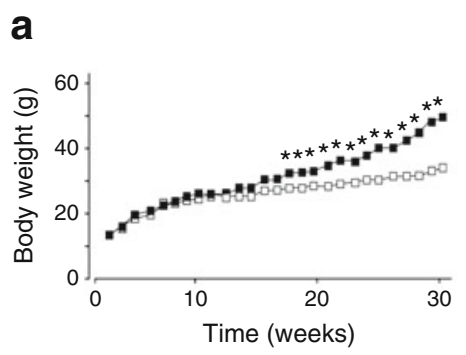

b

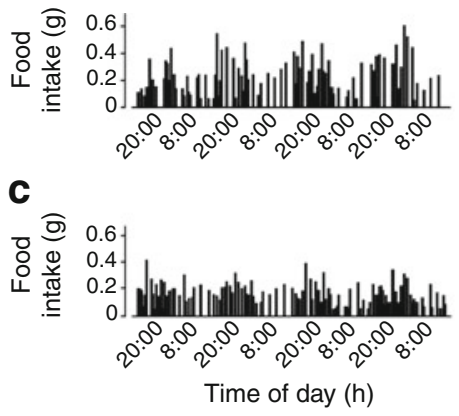

d

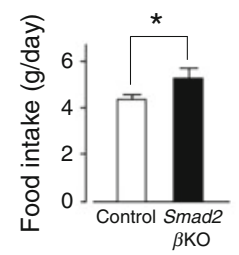

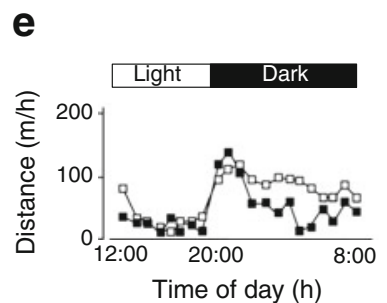

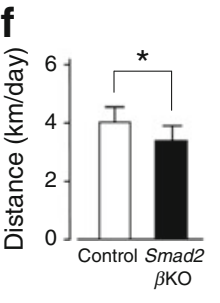

Fig. 2 General characteristics of late-onset obesity in $\operatorname{Smad} 2 \beta \mathrm{KO}$ mice fed on a normal chow diet. (a) Growth curves of Smad $2 \beta \mathrm{KO}$ mice (black squares, $n=28$ ) and control Rip mice (white squares, $n=24)$. (b-d) Food intake in Smad $2 \beta \mathrm{KO}$ mice (c) was increased compared with control (b) but its circadian rhythmicity was not altered. $(\mathbf{e}, \mathbf{f})$ The locomotive activity of Smad $2 \beta \mathrm{KO}$ mice (black squares) during the active dark cycle g

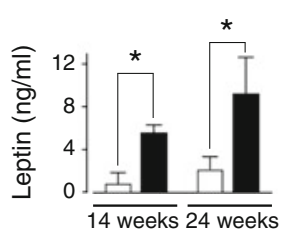

$\mathbf{h}$

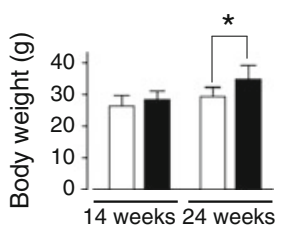

was significantly lower than that of control Rip mice (white squares). $(\mathbf{g}, \mathbf{h})$ Fasting serum leptin levels in Smad $2 \beta \mathrm{KO}$ (black bars, $n=3$ ) and control Rip (white bars, $n=6$ ) mice at 14 and 24 weeks of age. High levels of leptin (g) were already observed in $\operatorname{Smad} 2 \beta \mathrm{KO}$ mice at 14 weeks when their body weight was indistinguishable from that of control Rip mice $(\mathbf{h}) ;{ }^{*} p<0.01$

(Fig. 4a), a large inward current developed at $-60 \mathrm{mV}$, within 3 min of establishing the conventional whole-cell configuration (2.6 $\pm 0.1 \mathrm{~min}, n=56$ ); the amplitude gradually increased to a maximum of $\sim 1,000 \mathrm{pA}(1,038 \pm 394 \mathrm{pA}, n=56)$ at $\sim 7 \mathrm{~min}(6.5 \pm 0.2 \mathrm{~min}, n=56)$. The basal membrane current was suppressed by subsequent application of $5 \mathrm{mmol} / \mathrm{B} \mathrm{Ba}^{2+}$, an inwardly rectifying $\mathrm{K}^{+}$channel blocker. However, in Smad $2 \beta \mathrm{KO}$ beta cells, little inward current was apparent at 4 min (Fig. 4b). In some Smad $2 \beta \mathrm{KO}$ cells, an inward current was gradually evoked, although its peak amplitude was significantly smaller than in controls. The time to peak amplitude was significantly shorter in control $(6.5 \pm 0.2 \mathrm{~min}, n=56)$ than in Smad $2 \beta \mathrm{KO}$ (10.5 $\pm 0.4 \mathrm{~min}, n=43$ ) beta cells (Fig. $4 \mathrm{c}$ ), and the current density $(\mathrm{pA} / \mathrm{pF})$ was significantly higher (control, $74.8 \pm 4.4 \mathrm{pA} / \mathrm{pF}, n=56$ vs $\operatorname{Smad} 2 \beta \mathrm{KO}, 39.5 \pm 5.0 \mathrm{pA} / \mathrm{pF}$, $n=45$ : Fig. 4 d).

To obtain current-voltage relationships, four ramp pulses were applied in control beta cells (Fig. 5a). Figure 5b shows the average of four ramp currents recorded from the cell used in Fig. 5a on three different occasions: just after establishing the conventional whole-cell configuration (control), at maximal current activation and following application of $5 \mathrm{mmol} / \mathrm{l}$ $\mathrm{Ba}^{2+}$. The mean $\mathrm{Ba}^{2+}$-sensitive current (subtraction of mean current in $\mathrm{Ba}^{2+}$ from that at maximal activation) showed evidence of strong inward rectification (Fig. $5 \mathrm{c}$ ), with a reversal potential of $-1.0 \mathrm{mV}$ in symmetrical $140 \mathrm{mmol} / 1 \mathrm{~K}^{+}$solutions. Similar voltage protocols were performed in $\operatorname{Smad} 2 \beta \mathrm{KO}$ beta cells (Fig. $5 \mathrm{~d}$, e); the $\mathrm{Ba}^{2+}$-sensitive current also exhibited 


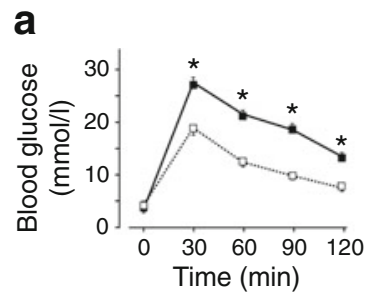

\section{b}
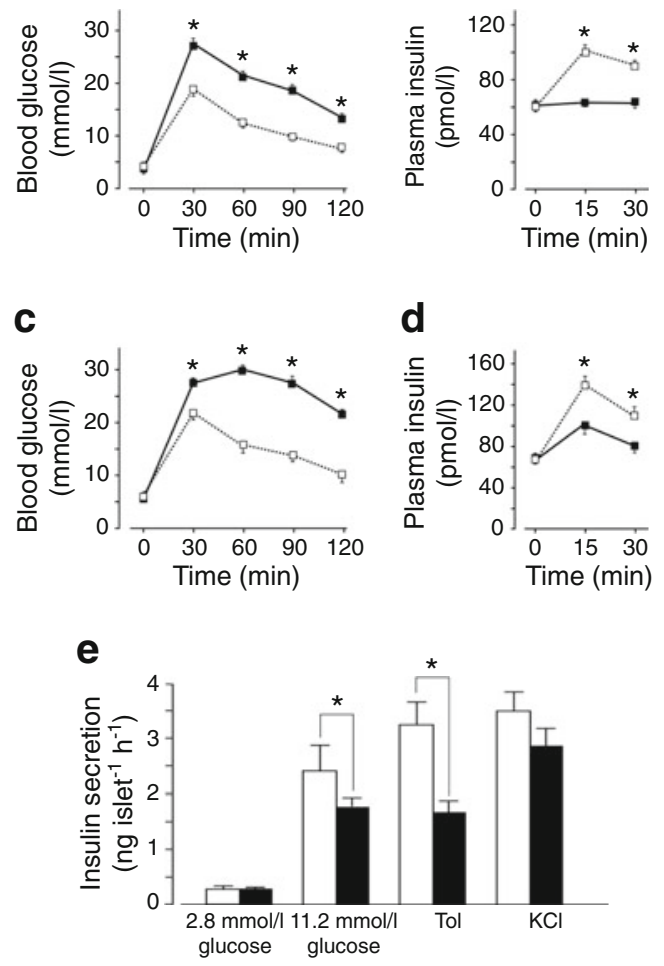

Fig. 3 Impaired glucose-stimulated insulin secretion. Some of the SEM bars are smaller than the symbols. (a-d) Glucose tolerance testing of 8 -week-old (a, b) $(n=10$ per group) and 20-week-old (c, d) $(n=12$ per group) male mice. Blood glucose $(\mathbf{a}, \mathbf{c})$ and serum insulin $(\mathbf{b}, \mathbf{d})$ levels in Smad $2 \beta \mathrm{KO}$ mice (black squares) and control Rip mice (white squares) after glucose injection. (e) Insulin secretion from isolated islets. Smad $2 \beta \mathrm{KO}$ islets (black bars) shows a defective insulin secretory response to $11.2 \mathrm{mmol} / \mathrm{l}$ glucose and $0.5 \mathrm{mmol} / \mathrm{l}$ tolbutamide (Tol) compared with control mice (white bars). Insulin secretion was assessed in triplicate in each group. Data are expressed as means \pm SEM. ${ }^{*} p<0.01$

strong inward rectification (Fig. 5f). The concentrationdependent inhibitory effects of two sulfonylurea drugs, tolbutamide (control, inhibitory dissociation constant $\left.\left[K_{i}\right]=145 \mu \mathrm{mol} / 1 ; \operatorname{Smad} 2 \beta \mathrm{KO}, K_{i}=138 \mu \mathrm{mol} / 1\right)$ and glibenclamide (control, $K_{i}=57 \mu \mathrm{mol} / \mathrm{l} ; \operatorname{Smad} 2 \beta \mathrm{KO}, K_{i}=52$ $\mu \mathrm{mol} / \mathrm{l}$ ), on the basal inward current at $-60 \mathrm{mV}$, were similar when comparing Smad $2 \beta \mathrm{KO}$ and control cells (Fig. 5g). Realtime PCR revealed no significant differences in either Kir6.2 or SUR1 expression between control and Smad2 $\beta \mathrm{KO}$ islets (Fig. 5h, i). Kir6.2 and SUR1 immunoreactivity was detected in beta cells from both $\operatorname{Smad} 2 \beta \mathrm{KO}$ and control mice (Fig. $5 \mathrm{j}$ ).

Islet hyperplasia in Smad2 $\beta$ KO mice Smad2 haploinsufficiency results in adult endocrine pancreatic defects $[14,15]$, with reduced islet area and insulin content and impaired glucose tolerance. Therefore, histological and immunohistological analyses of pancreatic islets were performed. SMAD2 disruption had no effect on islet formation or architecture. Immunostaining for insulin and glucagon revealed typical islet morphology (a core of insulin-positive cells with a mantle of glucagon-positive cells) in both Smad $2 \beta \mathrm{KO}$ and control mice (Fig. 6a), indicating that islet beta cell lineage specification may not require SMAD2. Surprisingly, in contrast to the islet hypoplasia reported in Smad2 heterozygous mice, beta cell mass (i.e. islet size) was significantly greater in Smad $2 \beta \mathrm{KO}$ mice than in controls (Fig. 6b, c). Interestingly, morphometric analysis revealed that islet hyperplasia in $\operatorname{Smad} 2 \beta \mathrm{KO}$ mice increased with age. The average islet size at 7 and 23 weeks was $12,400 \pm 1,800 \mu \mathrm{m}^{2}$ $(n=628)$ and $14,700 \pm 4,600 \mu^{2}(n=239)$ in controls, respectively, and 17,800 $\pm 2,800 \mu \mathrm{m}^{2}(n=743)$ and $30,800 \pm 5,400 \mu \mathrm{m}^{2}$ $(n=399)$ in Smad2 $\beta$ KO mice (Fig. 6b, c). Smad2 $\beta$ KO mice also showed increased and decreased proportions of large and small islets, respectively (Fig. 6d, e). Islet hyperplasia was further demonstrated by a significant ( twofold) increase in pancreas insulin content in Smad2 $\beta \mathrm{KO}$ mice compared with controls (Fig. 6f, g), despite no differences in pancreas weights. At 23 weeks of age, the beta cell size was not different between control and mutant mice (cell area: $98.8 \pm 9.54 \mu \mathrm{m}^{2}$ vs $\left.97.8 \pm 8.82 \mu \mathrm{m}^{2}, n=110\right)$, indicating that islet enlargement was due to increased cell numbers. These results suggest that SMAD2 is required for regulation of beta cell mass, with increased proliferation underlying the greater beta cell mass. At 7 weeks, the percentage of cells incorporating BrdU was significantly higher in Smad $2 \beta \mathrm{KO}$ mice than in controls $(0.33 \%$ in Smad $2 \beta \mathrm{KO}$ vs $0.19 \%$ in control, per 100 islets; Fig. 6h). The percentage of TUNEL-positive cells in Smad $2 \beta$ KO mice at 23 weeks was indistinguishable from that in control mice (Fig. 6i).

\section{Discussion}

The present study investigated the role of SMAD2 in the differentiation and function of pancreatic beta cells. Mice lacking SMAD2 in beta cells and the hypothalamus develop late-onset obesity, impaired glucose tolerance and islet hyperplasia, suggesting that SMAD2 plays an important role in the control of metabolic homeostasis. Although unexpected, the late-onset obesity in Smad $2 \beta \mathrm{KO}$ mice is likely attributable to increased food intake rather than alterations in energy expenditure. Appetite is regulated by a complex system of central and peripheral signals, which modulate the response to nutrient ingestion $[23,24]$. Satiety signals originate in the gastrointestinal tract during a meal, with vagal nerve activity reaching the nucleus tractus solitarius (NTS) in the caudal brainstem. From the NTS, afferent fibres project to the arcuate nucleus where satiety signals are integrated with adiposity signals, including those generated by leptin and insulin. In our experimental mice, the Smad2 gene was partially deleted in the hypothalamus, possibly in cells expressing the insulin gene. These results suggest an important role for hypothalamic 
a
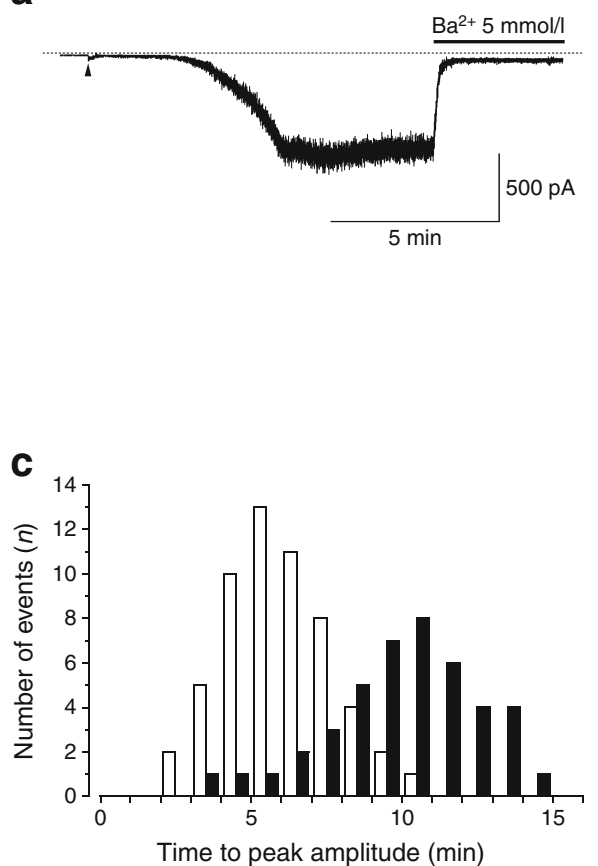

Fig. $4 \mathrm{Ba}^{2+}$-sensitive inward currents in pancreatic beta cells. (a) $\mathrm{Ba}^{2+}$-sensitive inward currents in pancreatic beta cells of control Rip mice were apparent at a holding potential of $-60 \mathrm{mV}$ when ATP was not included in the pipette solution. The arrowhead indicates the time when the conventional whole-cell recording was established. The dashed line indicates the zero current level. (b) $\mathrm{Ba}^{2+}$-sensitive inward currents in pancreatic beta cells of $S m a d 2 \beta \mathrm{KO}$ mice were apparent at $-60 \mathrm{mV}$ when

SMAD2 in the regulation of food intake and strongly indicate a need for further research into this important area.

The most striking phenotypes in Smad $2 \beta \mathrm{KO}$ mice are impaired glucose tolerance and islet enlargement. The increased number of cells incorporating BrdU in Smad2 $\beta \mathrm{KO}$ mice indicates that SMAD2 is an important regulator of beta cell proliferation. This islet hyperplasia phenotype appears contradictory to previous observations in mice heterozygous for the Smad2 null allele [13, 15]. In our study, Smad2 was selectively disrupted in islet beta cells using a Cre transgene driven by a rat insulin gene promoter. Within the framework of cell-cell interactions, it remains unclear which cells transmit and which receive TGF- $\beta$ /activin signals. Better characterisation of the cellular expression patterns of TGF- $\beta$ signalling components is required, including the potential ligands involved. Furthermore, in vitro tissue recombination experiments will allow testing of whether pancreatic phenotypes resulting from specific mutations are cell autonomous or non-autonomous [25]. Nonetheless, our results show that SMAD2 is required for glucose-responsive insulin secretion and maintenance of cell mass in beta cells.

It will be important to elucidate the upstream signalling pathways, including ligands and receptors, that recruit SMAD2 in the regulation of beta cell function. Mice lacking b

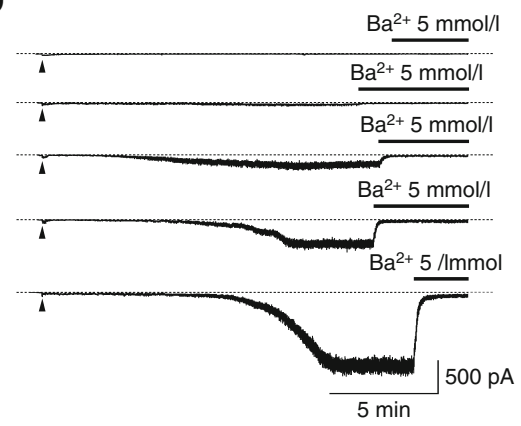

d

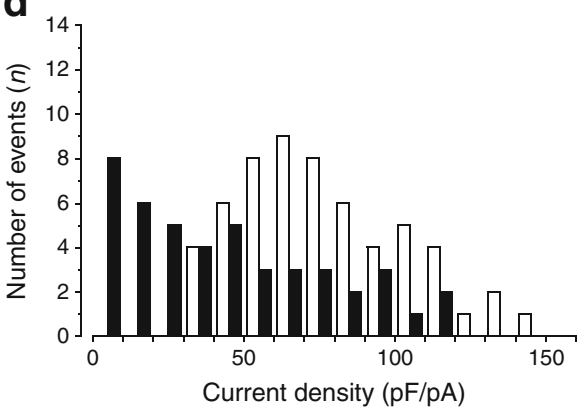

ATP was not included in the pipette solution. A wide variety of $\mathrm{K}_{\text {ATP }}$ currents were evident in Smad $2 \beta \mathrm{KO}$ beta cells. (c) Comparison of the time to peak amplitude of the $\mathrm{Ba}^{2+}$-sensitive inward current between control Rip (white bars) and Smad $2 \beta \mathrm{KO}$ mice (black bars). (d) Comparison of the current density of the $\mathrm{Ba}^{2+}$-sensitive inward current between control Rip (white bars) and Smad $2 \beta \mathrm{KO}$ mice (black bars)

activin receptor-like kinase 7 (ALK7), a type I receptor for activin B, show progressive hyperinsulinaemia [26]. Although activin B causes SMAD2 phosphorylation in ALK7-null beta cells, activin B signals through ALK7 to negatively regulate glucose-dependent $\mathrm{Ca}^{2+}$ influx and insulin secretion; hence, ALK7 is a negative regulator of beta cell function [26]. However, glucose-dependent insulin secretion was severely impaired in Smad2 $\beta \mathrm{KO}$ mice, suggesting that SMAD2 is unlikely to act in the activin B/ALK7 signalling pathway. Nodal, a member of the TGF- $\beta$ family, has been reported to induce apoptosis and suppress proliferation of clonal beta cell lines through activation of ALK7 signalling [27]. We reported a genetic interaction between nodal and SMAD2 during early embryogenesis [14]. In the present experiments, beta cell proliferation was increased in Smad $2 \beta \mathrm{KO}$ islets; we therefore suggest that nodal/ALK7 signalling may be one of the upstream candidates. Another study has shown that mice lacking the activin inhibitor follistatin-like 3 (FSTL3) develop enlarged pancreatic islets and moderate increases in serum insulin levels [28], indicating that FSTL3 may be involved, at least in part, in SMAD2 signalling. ALK7 and FSTL3 are expressed in control islets, and their expression levels are not altered in Smad2 $\beta \mathrm{KO}$ islets (data not shown). It has been proposed that growth differentiation factor 11 (GDF11, a 
a

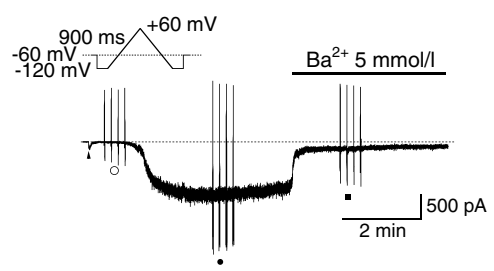

d

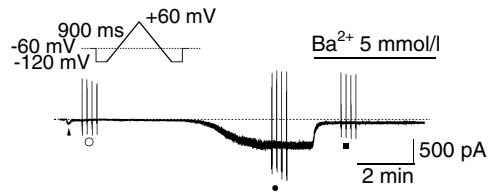

b
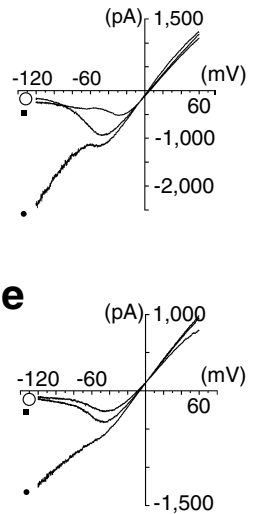

C

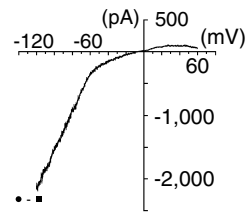

f

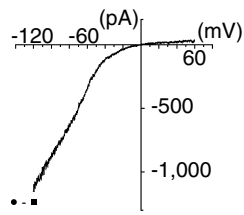

g

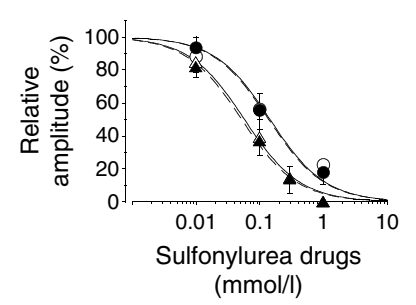

h

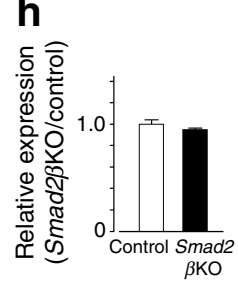

i

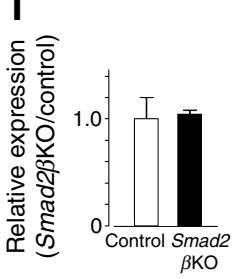

j

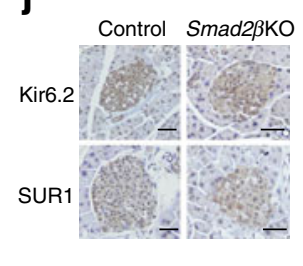

Fig. 5 Electrophysiological and pharmacological properties of $\mathrm{Ba}^{2+}$-sensitive inward currents in pancreatic beta cells. (a) $\mathrm{Ba}^{2+}$-sensitive inward currents in pancreatic beta cells of control Rip mice were apparent at $-60 \mathrm{mV}$ when ATP was not included in the pipette solution. The arrowhead indicates the time when the conventional whole-cell recording was established. The dashed line indicates the zero current level. The vertical deflections indicate times at which triangular ramp potential pulses (see inset) were applied under each experimental condition. (b) Mean current for four ramp potential pulses applied at $15 \mathrm{~s}$ intervals under each experimental condition in pancreatic beta cells of control mice. (c) Difference between the mean membrane current at the time of maximal activation and that in the presence of $5 \mathrm{mmol} / \mathrm{B} \mathrm{Ba}^{2+}$ (black circle - black square). (d) $\mathrm{Ba}^{2+}$-sensitive inward currents in pancreatic beta cells of Smad $2 \beta \mathrm{KO}$ mice were apparent at $-60 \mathrm{mV}$ when ATP was not included in the pipette solution. The arrowhead indicates the time when the conventional whole-cell recording was established. The dashed line indicates the zero current level. The vertical deflections indicate times at which triangular ramp potential pulses (see inset) were applied under each experimental condition. (e) Mean current for four ramp potential pulses applied at $15 \mathrm{~s}$ intervals under each experimental condition in pancreatic beta cells of Smad2 $\beta \mathrm{KO}$ mice. (f) Difference between the mean membrane current at the time of maximal activation and that in the presence of $5 \mathrm{mmol} / 1 \mathrm{Ba}^{2+}$ (black circle - black square). (a-f, control, white circles; activation, black circles; $\mathrm{Ba}^{2+}$, black squares). (g) Concentration-response curves for two sulfonylurea drugs, glibenclamide (triangles) and tolbutamide (circles), in the pancreatic beta cells of control Rip (white symbols) and Smad $2 \beta \mathrm{KO}$ mice (black symbols). The peak amplitude of the inward current just before application of sulfonylurea drugs was normalised to unity. The following values were used for curve fitting in control mice: glibenclamide, $K_{i}=57 \mu \mathrm{mol} / 1, \mathrm{n}_{\mathrm{H}}=1.0$; tolbutamide, $K_{i}=145 \mu \mathrm{mol} / 1, \mathrm{n}_{\mathrm{H}}=1.0$. The following values were used for Smad2 $\beta \mathrm{KO}$ mice: glibenclamide, $K_{i}=52 \mu \mathrm{mol} / 1, \mathrm{n}_{\mathrm{H}}=1.0$; tolbutamide; $K_{i}=138 \mu \mathrm{mol} / 1, \mathrm{n}_{\mathrm{H}}=1.0$. Each symbol indicates the mean of five observations \pm SEM. The $x$-axis is indicated on a base 10 logarithmic scale. (h, i) Quantitative analysis of Kir6.2 (h) and SUR1 (i) expression in control and Smad $2 \beta \mathrm{KO}$ islets using real-time PCR techniques. (j) Immunohistochemical analysis of Kir6.2 and SUR1 in pancreatic beta cells of control Rip and Smad $2 \beta \mathrm{KO}$ mice. Scale bars, $50 \mu \mathrm{m}$ member of the TGF- $\beta$ family) signals through SMAD2; indeed, mice heterozygous for Smad2 have increased numbers of neurogenin-3-positive cells, progenitors of beta cells, and reduced beta cell mass, reminiscent of Gdf11 KO mice. These findings suggest that GDF11 acts via SMAD2 to promote beta cell differentiation during development [29]. It is currently not known whether GDF11 and nodal have important physiological functions in adult islets. Although GDF11 and/or nodal may be plausible candidates, redundancy of this function seems likely, given that activins are also expressed in the pancreas [30]. Collectively, SMAD2 may be a downstream signal transducer for multiple ligands of the TGF- $\beta$ /activin family. Further investigations are required to delineate the intricate signalling pathways that involve SMAD2 in pancreatic beta cells.

$\mathrm{K}_{\mathrm{ATP}}$ channels play an important role in the regulation of insulin secretion, coupling glucose metabolism to electrical activity in beta cells. $\mathrm{K}_{\mathrm{ATP}}$ channels are heteromeric, consisting of at least two subunit proteins: (1) Kir6.x, which forms the $\mathrm{K}^{+}$ conducting pore of an inwardly rectifying $\mathrm{K}^{+}$channel and (2) a modulatory SUR, a member of the ATP-binding cassette protein superfamily. It is generally accepted that Kir6.x proteins are responsible for $\mathrm{K}^{+}$permeation while SUR.x proteins determine the nucleotide sensitivity and the pharmacology of $\mathrm{K}_{\text {ATP }}$ channels (including channel-opening properties and sulfonylurea binding sites), and that molecular combinations of 
a

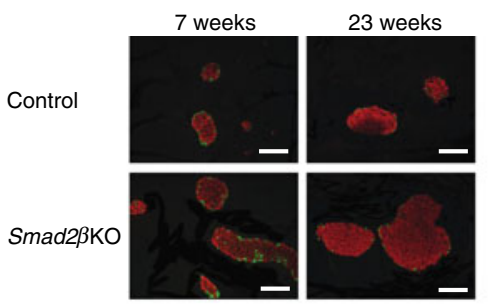

d
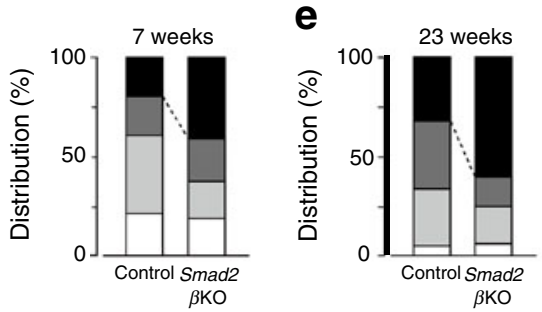

h

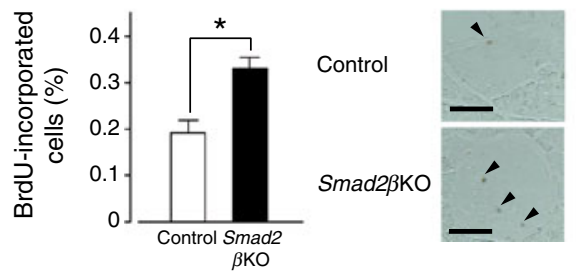

Fig. 6 Age-dependent increment of beta cell mass. (a) Progressive islet enlargement in the pancreas of Smad $2 \beta \mathrm{KO}$ mice. Immunofluorescence staining for insulin (red) and glucagon (green) is shown for control Rip mice and Smad $2 \beta \mathrm{KO}$ mice at 7 and 23 weeks of age. Bars represent $100 \mu \mathrm{m}$. (b-e) Morphometric analysis of islet area in pancreases from 7-week-old and 23-week-old control Rip and Smad2 $\beta$ KO mice. Smad $2 \beta$ KO mice: 7 weeks, $n=223 ; 23$ weeks, $n=219$. Control Rip mice: 7 weeks, $n=196$; 23 weeks, $n=208$. The distribution of islet areas $<2,500 \mu \mathrm{m}^{2}$ (white), 2,500-5,000 $\mu^{2}$ (light grey), 5,000-10,000 $\mu^{2}$ (dark grey) or $>10,000 \mu \mathrm{m}^{2}$ (black) is shown as a percentage of the islets

Kir6.2/SUR1 represent the predominant isoforms in beta cells $[31,32]$. In the present experiments, the current density of $\mathrm{K}_{\text {ATP }}$ channels was much smaller in Smad2 $\beta \mathrm{KO}$ beta cells than in controls. In contrast, the electrophysiological (including inward rectification and current-voltage relationships) and pharmacological (including sulfonylurea drug sensitivity and $\mathrm{Ba}^{2+}$ sensitivity) properties of $\mathrm{K}_{\mathrm{ATP}}$ currents were not altered in Smad $2 \beta \mathrm{KO}$ beta cells compared with controls. The simplest explanation is that $\mathrm{K}_{\mathrm{ATP}}$ channel density may be reduced in Smad2 $\beta \mathrm{KO}$ beta cells in comparison with control cells. However, both real-time PCR and immunohistochemical studies indicated that the immunoreactivity of Kir6.2 and SUR1 proteins was not significantly different between Smad $2 \beta \mathrm{KO}$ and control mice. Moreover, the time to peak amplitude of $\mathrm{K}_{\mathrm{ATP}}$ currents in Smad2 $\beta \mathrm{KO}$ beta cells was longer than in controls. This suggests that signalling through SMAD2 may modulate $\mathrm{K}_{\text {ATP }}$ channel kinetics in beta cells. Further studies will elucidate the relationship between SMAD2 and $\mathrm{K}_{\mathrm{ATP}}$ channel activity in beta cells.
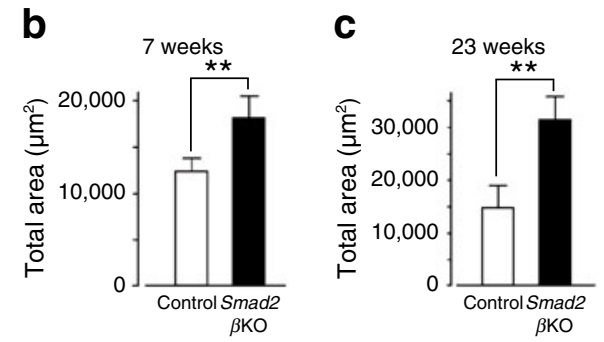

f
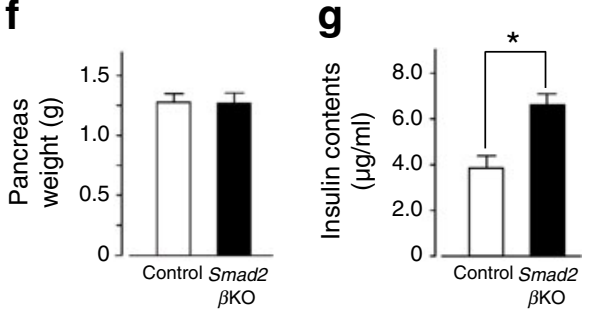

i

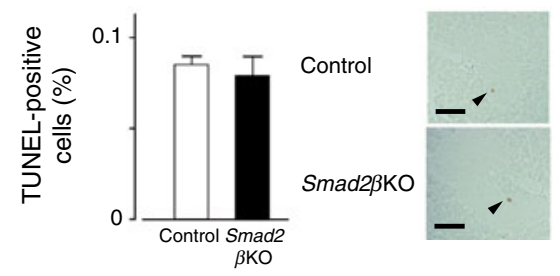

measured. ${ }^{* *} p<0.001$ for control Rip vs $\operatorname{Smad} 2 \beta \mathrm{KO}$ mice. The results are expressed as the mean \pm SEM. (f, g) Pancreas weight and insulin content in whole pancreases from control Rip and Smad2 $\beta$ KO mice. ${ }^{*} p<0.01$. (h, i) Analyses of beta cell proliferation and apoptosis in the control and mutant mice at 7 and 23 weeks of age, respectively. (h) BrdU-incorporated nuclei are indicated by arrowheads. (i) TUNEL-positive cells are indicated by arrowheads. Quantitative analyses of beta cell proliferation and apoptosis in the control and mutant mice are shown. The results are expressed as means \pm SEM (100 islets from each mouse). ${ }^{*} p<0.01$. Scale bars, $5 \mu \mathrm{m}$

In conclusion, our studies provide evidence for the regulation of crucial aspects of beta cell function and proliferation through SMAD2 signalling pathways. Identification of the signalling pathways that maintain and improve pancreas islet functions will ultimately provide novel strategies for the treatment of diabetes.

Acknowledgements We thank Yuriko Hamaguchi and Akiko Nakano (Kyushu University, Graduate School of Medical Sciences, Japan) for technical assistance and Eri Matsubara, Hisaya Kawate and Keizo Ohnaka (Kyushu University, Graduate School of Medical Sciences, Japan) for their technical support and helpful discussion.

Funding This work was supported in part by the Japanese Society for the Promotion of Science (JSPS) KAKENHI (MN, grant number 23591356; RT, grant number 23390247) and Grants-in-Aid for Research Fellowship for Young Science Foundation and Banyu Science Foundation (LW). The work of MN was supported by a grant from the Medical Research Encouragement Prize of The Japan Medical Association. The research was also supported by the JSPS Funding Program for Next Generation World-Leading Researchers (NT, grant number LS096). 
Duality of interest The authors declare that there is no duality of interest associated with this manuscript.

Contribution statement MN and NT designed the study. MN, HLZ, LW, HM and NT acquired and analysed data. MN, RT and NT contributed to interpretation of data. MN and NT wrote the manuscript and MN, HLZ, LW, HM, RT and NT revised it. NT was responsible for the conception of the study and drafting the article. All authors approved the final version.

\section{References}

1. Kim SK, Hebrok M (2001) Intercellular signals regulating pancreas development and function. Genes Dev 15:111-127

2. Kim SK, MacDonald RJ (2002) Signaling and transcriptional control of pancreatic organogenesis. Curr Opin Genet Dev 12:540-547

3. Massagué J, Blain SW, Lo RS (2000) TGF $\beta$ signaling in growth control, cancer, and heritable disorders. Cell 103:295-309

4. Feng XH, Derynck R (2005) Specificity and versatility in TGF- $\beta$ signaling through Smads. Annu Rev Cell Dev Biol 21:659-693

5. Massagué J, Chen YG (2000) Controlling TGF-beta signaling. Genes Dev 14:627-644

6. Ogawa K, Abe K, Kurosawa N et al (1993) Expression of alpha, beta $\mathrm{A}$ and beta $\mathrm{B}$ subunits of inhibin or activin and follistatin in rat pancreatic islets. FEBS Lett 319:217-220

7. Yamanaka Y, Friess H, Büchler M, Beger HG, Gold LI, Korc M (1993) Synthesis and expression of transforming growth factor beta1 , beta- 2 , and beta- 3 in the endocrine and exocrine pancreas. Diabetes 42:746-756

8. Wada M, Shintani Y, Kosaka M, Sano T, Hizawa K, Saito S (1996) Immunohistochemical localization of activin A and follistatin in human tissues. Endocr J 43:375-385

9. Yamaoka T, Idehara C, Yano M et al (1998) Hypoplasia of pancreatic islets in transgenic mice expressing activin receptor mutants. J Clin Invest 102:294-301

10. Florio P, Luisi S, Marchetti P et al (2000) Activin A stimulates insulin secretion in cultured human pancreatic islets. J Endocrinol Investig 23:231-234

11. Totsuka Y, Tabuchi M, Kojima I, Shibai H, Ogata E (1988) A novel action of activin A: stimulation of insulin secretion in rat pancreatic islets. Biochem Biophys Res Commun 156:335-339

12. Totsuka Y, Tabuchi M, Kojima I, Eto Y, Shibai H, Ogata E (1989) Stimulation of insulin secretion by transforming growth factor-beta. Biochem Biophys Res Commun 158:1060-1065

13. Kim SK, Hebrok M, Li E et al (2000) Activin receptor patterning of foregut organogenesis. Genes Dev 14:1866-1871

14. Nomura M, Li E (1998) Smad2 role in mesoderm formation, leftright patterning and craniofacial development. Nature 393:786-790

15. Goto Y, Nomura M, Tanaka K et al (2007) Genetic interactions between activin type IIB receptor and Smad 2 genes in asymmetrical patterning of the thoracic organs and the development of pancreas islets. Dev Dyn 236:2865-2874

16. Zhang Y-Q, Kanzaki M, Furukawa M et al (1999) Involvement of Smad proteins in the differentiation of pancreatic AR42J cells induced by activin A. Diabetologia 42:719-727

17. Smart NG, Apelqvist ÅA, Gu X et al (2006) Conditional expression of Smad7 in pancreatic beta cells disrupts TGF-beta signaling and induces reversible diabetes mellitus. PLoS Biol 4(e39):0200-0209

18. Lin HM, Lee JH, Yadav H et al (2009) Transforming growth factorbeta/Smad3 signaling regulates insulin gene transcription and pancreatic islet beta-cell function. J Biol Chem 284:12246-12257

19. Wang L, Nomura M, Goto Y et al (2011) Smad2 protein disruption in the central nervous system leads to aberrant cerebellar development and early postnatal ataxia in mice. J Biol Chem 286:18766-18774

20. Lacy PE, Kostianovsky M (1967) Method for the isolation of intact islets of Langerhans from the rat pancreas. Diabetes 16:35-39

21. Fan W, Yanase T, Nomura M et al (2005) Androgen receptor null male mice develop late-onset obesity caused by decreased energy expenditure and lipolytic activity but show normal insulin sensitivity with high adiponectin secretion. Diabetes 54:1000-1008

22. Teramoto N, Zhu HL, Shibata A et al (2009) ATP-sensitive $\mathrm{K}^{+}$ channels in pig urethral smooth muscle cells are heteromultimers of Kir6.1 and Kir6.2. Am J Physiol 296:F107-F117

23. Valassi E, Scacchi M, Cavagnini F (2008) Neuroendocrine control of food intake. Nutr Metab Cardiovasc Dis 18:158-168

24. Sainsbury A, Zhang L (2012) Role of the hypothalamus in the neuroendocrine regulation of body weight and composition during energy deficit. Obes Rev 13:234-257

25. Ahlgren U, Jonsson J, Edlund H (1996) The morphogenesis of the pancreatic mesenchyme is uncoupled from that of the pancreatic epithelium in IPF1/PDX1-deficient mice. Development 122:1409-1416

26. Bertolino P, Holmberg R, Reissmann E, Andersson O, Berggren PO, Ibáñez CF (2008) Activin B receptor ALK7 is a negative regulator of pancreatic beta-cell function. Proc Natl Acad Sci U S A 105:72467251

27. Zhao F, Huang F, Tang M et al (2012) Nodal induces apoptosis through activation of the ALK7 signaling pathway in pancreatic INS-1 $\beta$-cells. Am J Physiol Endocrinol Metab 303:E132-E143

28. Mukherjee A, Sidis Y, Mahan A et al (2007) FSTL3 deletion reveals roles for TGF-beta family ligands in glucose and fat homeostasis in adults. Proc Natl Acad Sci U S A 104:1348-1353

29. Harmon EB, Apelqvist AA, Smart NG, Gu X, Osborne DH, Kim SK (2004) GDF11 modulates $\mathrm{NGN}^{+}$islet progenitor cell number and promotes beta-cell differentiation in pancreas development. Development 131:6163-6174

30. McPherron AC (2010) Metabolic functions of myostatin and GDF11. Immunol Endocr Metab Agents Med Chem 10:217-231

31. Aguilar-Bryan L, Bryan J (1999) Molecular biology of adenosine triphosphate-sensitive potassium channels. Endocr Rev 20:101-135

32. Seino S (1999) ATP-sensitive potassium channels: a model of heteromultimeric potassium channel/receptor assemblies. Annu Rev Physiol 61:337-362 